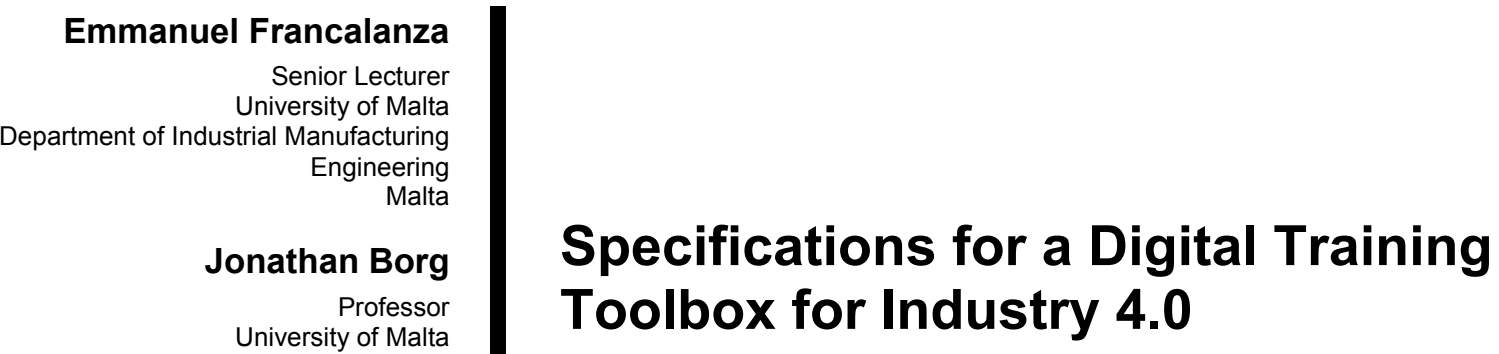

Department of Industrial Engineering Malta

The development in the past decade of Industry 4.0 technologies has brought many new opportunities to manufacturers. The increased digitization of manufacturing operations has led to new modes of production and product development. This digitization has also increased the quantity of sensorial data which is easily available and which can be used to support real-time decision making. That said, with the opportunities come as well a number of challenges. Principally amongst these is a skills gap within the workforce. Without the required knowledge organisations will find it difficult and complex not only to employ these technologies, but also to develop the new manufacturing paradigms of tomorrow. Hence an innovative and effective training methodology is required to address this skills and knowledge gap. As part of the development of this methodology, this paper presents the finding of a study carried out to analyse the knowledge and skills gap, preferred learning methods and styles of trainers, current and past students in engineering Higher Education Institutions. This requirements analysis has led to the specifications for a Digital Training Toolbox, which can be utilised to support the implementation of Inudstry 4.0 technologies and organisational concepts.

\section{Magnus Lundgren}

Researcher

KTH Royal Institute of Technology Digital Smart Production

Sweden

Catalin Amza

Professor

Polytechnic University of Bucharest CAMIS
Keywords: Education, Industry 4.0, Learning Methods, Learning Styles, Digitization.

\section{INTRODUCTION AND PROBLEM BACKGROUND}

It is a known fact that the world of work is increasingly becoming digitized, this is evident from what has been termed the fourth industrial revolution (Industry 4.0). As explained by Putnik et al. [1] Industry 4.0 represents an emergent context for industrial activities, where physical equipment, controlling processes and sup-porting information systems are closer than ever.

As part of its Digital Single Market Strategy (2018), the European Commission wants to help all industrial sectors exploit new technologies and manage a transition to a smart, Industry 4.0 industrial system. This revolution is driving technology development within industry at such a fast pace that even Higher Education Institution (HEI) educators are finding difficulties to catch up and keep abreast of the latest developments. These skills mismatches imply that they also encoun-

Received: January 2021, Accepted: September 2021

Correspondence to: Dr Emmanuel Francalanza

Department of Industrial Manufacturing Engineering

University of Malta

E-mail: emmanuel.francalanza@um.edu.mt

doi: $10.5937 /$ fme2104893F

(C) Faculty of Mechanical Engineering, Belgrade. All rights reserved tering difficulties in transferring knowledge effectively to a new generation of learners. Furthermore, previous generations of learners who are currently working in industry did not receive training in technologies such as AI, big data analytics and cloud technology which are the drivers of change. As mentioned in the World Economic Forum "The Future of Jobs Report" (2018) upskilling of the manufacturing sector is required for it to remain competitive: $52 \%$ of the current European workforce needs retraining before 2022 .

In fact, the EU via "DIGITALEUROPE - Our Call to Action towards 2025", (2018) calls on education leaders to ensure a greater presence of the digital sector in tertiary and adult education to fuel the digital labor sector faster with the skills required by digital emplo-yers.

Pinheiro et al. [2] argue that, based on an fractal analysis of a number of indicators, it is not possible to claim that the fourth industrial revolution is truly underway, implying that Industrial 4.0 may stil be a vision of the future. This means that we have a greater need to prepare the workforce with the required skill set to really utilise the tools and concepts at their disposal to provide a disruptive rather than incremental innovation. 
This situation creates an urgent need for HEI educators and stakeholders be given the chance to catch up with industry 4.0 technologies such as AI/Blockchain in Industry, IoT, 3D Printing, VR and AR, Robotics, Cybersecurity, Big Data, Cloud Computing, Drones, etc. As outlined in the "Digital Transformation Scoreboard" (2018) whilst digital technologies have already started to be adopted by EU industry, the multi-modal adoption of newer technologies is still at an early stage leaving many more opportunities to be exploited. In fact, nearly 9 out of 10 European companies consider digital technologies an opportunity. Therefore, in order to be ready for tomorrow's opportunities and demands current and future HEI learners require training in the latest and advanced technologies and approaches. Similarly there are previous HEI learners who are currently working in industry and have skills mismatches, and hence require training in industry 4.0 technologies.

As argued by Stadnicka et al. [3] the human factor plays a key role in the industry of the future, and although, the number of workers needed in factories of the future may decrease, the requiremenets concerning employees skills have been increasing.

Further to this, as noted by Joksimović et al. [4] classical teacher centered pedagogical methods lead to learners being passive and bored in class, losing interest in the subject, and in general a slower progress. The implementation of inverted classroom pedagogical methods can effectively lead towards an increase in the students' success rate and their average mark [4].

The main aim of this project is to develop an effective pedagogic approach to address this Industry 4.0 skills gap, termed the ICARUS open and digital training toolbox. The first step to develop this training toolbox is to determine and define the specific training requirements of HEI educators and learners. This paper highlights how the ICARUS project partners have de-veloped and undertaken a study to understand the trai-ning requirements of HEI educators and learners. The analysis of this information will provide the underlying foundation for the training content and toolbox training functions.

Therefore, in order to understand how it is best to deliver the training content developed by the ICARUS consortium it was decided to investigate the preferred learning methods and the learning styles of the stakeholders. Learning methods are the pedagogic approaches which are utilised to transfer knowledge. These can range from the traditional lecture in HEIs to various forms of digital and online learning. Learning styles refer to the preferential way in which the student absorbs, processes, comprehends and retains information. Learners exhibit various learning styles ranging from the visual to the auditory to the kinesthetic learner.

The aim of this work is therefore to answer the question: "How do they Engineering HEI learn effectively". This will support the development of the specifications for a training toolbox which can be adapted based on the learning style of the learner.

\section{LITERATURE REVIEW}

The need to develop effective training content in relation to Industry 4.0 is explored by a number of authors.
Whilst acknowledging that Industry 4.0 represents one of the most challenging themes for engineering education Motyl et al. investigate which are the necessary skills and expertise young engineers require to be ready for the Industry 4.0 framework [5].

Also there is a large literature on educational requirments related to the $21^{\text {st }}$ Century education. Obviously, as the Industry 4.0 belongs to the $21^{\text {st }}$ Century, the requirements for the education, or training, for Industry 4.0 is expected to be aligned with general vision for $21^{\text {st }}$ Century. The requirments for education in $21^{\text {st }}$ Century spans virtually over all educational issues such as, new skills identification and curriculum design, learning styles and tecnhologies, educational assessment, and others. Special requirements for the education in $21^{\text {st }}$ Century and on Industry 4.0, are related with paradigmatical issues, that is with the features of a new emerging paradigms related to Industry 4.0, and consequentely to the corresponding education.

Concerning the requirements for the skills and curriculum design, by Asian Development Bank [6] as cited in [7], a "new sets of skills linking to the broader world challenges we all face, are needed, to equip learners with the capacity to negotiate the complexities inherent in today's global and knowledge-driven-economy". By [8] curriculum design should include "effective virtual collaborative learning (VCL) environments" in order to provide to the learners new opportunities for learning experiences. Another aspect is encouragement of "ownership of the networks of learning which they create", including capacity for adaptability.

Concerning learning styles and tecnhologies, [9] referes the learning style model determined by two variables with the following values: "Active Experimentation - Doing" vs. "Reflective Observation - watching", and "Abstract Conceptualization - thinking" vs. "Concrete Experience - feeling". For implementation of selected learning styles, the educational technologies for Industry 4.0 have to include the new ones. Considering that use of computers and internet based technologies (for example email and web search) are already common place, it is necessary to include emerging educational technologies, inherent to Industry 4.0, such as mobile technologies (e.g. smartphones), social networks, and wearable devices [10].

Concerning educational assessment, in [11], besides the "classical" assessment technological requirements ("setting targets for student learning, showing students how they are progressing, promoting consistency in judging achievement/progress, setting requirements for qualification (certification), interpreting performances on tests, setting benchmarks for system monitoring, accountability for schools and systems"), some innovative constructs are suggested: "learning versus performance; development (time-extensive, assessing interim progress) versus achievement (time-limited, assessing degree of success); criterion-referencing versus norm-referencing; quality (how well) versus quantity (how much)".

Concerning paradigmatical issues, Industry 4.0 is characterized by much higher gradient of complexity increase than the previous industry paradigms. It means that the "complexity" is one of the keywords for the 
Industry 4.0, and consequently should be one of the keywords for the corresponded educational paradigms. From the other side, the cultural environment for Industry 4.0 is the postmodern. The postmoderninsm is characterized by departure from moderninsm, i.e. departure from "classical" models, in our context from "classical" models of education. The new models lead from pedagogy to heutagogy. While the pedagogy is defined as teacher-directed instruction based education, heutagogy is characterized as self-determined and selfdriven learning. This is recognized in so-called Education 3.0 paradigm, see e.g. [12], and [13].

Complexity is special issue to be considered in education which is one of the system thinking, i.e. complexity system thinking, as one of the bases of Education 3.0. Complexity as issue in education is discussed e.g. in [14].

The study in this paper was based effectively on the assumptions referred in the literature, from which a selection is referred above, especially related to the Education 2.0 paradigm, which actually dominates the univerisites, as well as on the Industry 4.0 features, i.e. concepts and technologies, widely accepted. The study investigated, among other questions, the students' readiness for transition from the "classical" skills requirements for manufacturing industry.

From the data collected in this study it is clear that young people are not aware of Industry 4.0 concepts such as the Smart Factory, but are more familiar with topics such as 3D printing, Virtual and Augmented Reality. Nafea and Toplu carried out argue a similar study on a sample of Canadian students [15]. Their results show that students are not yet ready for the transition towards Industry 4.0 skills. Hence they conclude that for students to be better prepared for the future workplace and the use of technology, the HEI sector needs to be streamlined with a more rigorous approach towards teacher training.

Given this need Schuster et al. argue that engineering education is faced with a large potential field of research, which ranges from the technical development and didactical conception of new Virtual Learning Environments (VLEs) to the investigation of students' acceptance or the proof of concept of the VLEs in terms of learning efficiency [16]. This research group emphasis that continuing this kind of research in development of effective training content is an important contribution towards a globalized, connected and digitalized working world in terms of industry 4.0.

As explained by Fedler and Silverman there may exist mismatches between common learning styles of engineering students and traditional teaching styles of engineering professors [17]. As a consequence of this, students may not be fully engaged within the training environment. As such Felder, and Silverman propose a learning style model which classifies engineering students based on a number of dimensions pertaining to the way they receive and process information. These dimensions vary from sensory to intuitive, visual to auditory, active to reflective, and sequential to global.

Othman and Amiruddin argue that a learning style can be perceived as an approach that one uses for the purpose of acquiring knowledge, positive skills and attitude [18]. As such, they propose that the VARK (Visual, Aural, Reading or Write and Kinesthetic) model as an effective learning style which can create a fascinating learning environment to students and stimulate students' senses in learning. Ayre et al. also argue that by redesigning approaches to teaching, learning and assessment of engineering courses to accommodate a range of learning styles can achieve an improvement in student engagement and satisfaction [19].

In developing the effective learning content a relationship between learning styles and learning methods has to be determined. In fact Huang et al. have empirically studied how various learning styles affects learners learning performance when utilizing eLearning by analyzing online participation [20]. This study concluded that learners whose learning style was characterized as "sensory" participated line more frequently and for a longer duration as compared to "intuitive" learners. This research reports that sensory learning style seems to be very compatible with the current e-learning environment.

It is evident from this body of work that there is therefore a need to develop effective learning approaches to address the Industry 4.0 skills and knowledge gap. Whilst a number of studies have investigated the use of learning styles in developing effective training approaches, further research work is required how this can be integrated together with Industry 4.0 learning content and methods which adequately address the needs of learners and trainers.

\section{METHODOLOGY FOR DEVELOPING THE DIGITAL TRAINING TOOLBOX SPECIFICATIONS}

\subsection{Research Method}

In order to address this gap, and as part of the ICARUS project, a Digital Training Toolbox is being developed. A user-centered methodology was therefore employed to understand the learner and trainer requirements and develop the training toolbox specifications. The systematic research methodology being employed is based on the User Centered Design Approach. The first step of this approach is to adopt a structured approach to understand the user needs. This was achieved by collecting the relevant information and views from the training toolbox users. Once these were collected a team of experts in HEI developed the toolbox specifications which will be described in Section 5 of this paper. This analysis of the requirements leads towards the design of an Industry 4.0 Digital Training Toolbox.

\subsection{Data Collection Method}

In order to determine the requirements of the digital training toolbox the researchers reviewed various types of quantitative, qualitative, and mixed research methods which can be utilized in engineering education [21]. Quantitative research studies allow the researchers to project the results of their analysis onto the larger population through an objective process. Hence the data collected, often through surveys administered to a sample or subset of the entire population, allows the 
researcher to generalize or make inferences. These type of quantitative studies also allow for the researchers to examine the relationships between various groups based on a set of hypothesis and research questions.

It was therefore decided that the best approach to collect the data and information required from the target groups relevant to this work was to utilise a quantitative research approach. In relation to this approach the use of an online questionnaire would be employed for the implementation.

This type of data collection method allowed the consortium to reach out to a wide ranging audience from various countries across Europe and ask about the different aspects required for the Industry 4.0 training toolbox. It was also determined that the appropriate format of data collection would be to utilise a closed ended question type questionnaire which would allow to quantitatively analyse the data once collected.

This questionnaire would then be distributed via an online survey platform such as google forms. This would enable all partner HEIs to utilise the same format and questions for homogeneity of the data being col-lected, as well as to facilitate data analysis at a later stage.

\subsection{Questionnaire Design}

The questionnaire design was split into three parts. The first part of the questionnaire was intended to determine the participant information, including the country of study as well as the target group. The groups targeted for this research were:

- $\quad$ (TG1) - Target Group 1 - Engineering Trainers/Educators in Higher Education Institutions

- (TG2) - Target Group 2 - Engineering learners having concluded courses in HEI and currently employed in industry

- $\quad$ (TG3) - Target Group 3 - Engineering learners currently undergoing courses in HEIs.

The second part of the questionnaire was aimed at determining what skills and knowledge is most required in order to bridge the Industry 4.0 gap amongst the different learning groups.

Lickert type questions (Scale 1 for least knowledgeable to Scale 5 most know-ledgeable) were utilised here to determine the perceived knowledge in different Industry 4.0 technology/enabler and organisational concept knowledge.

Part three of the questionnaire investigated the preferred learning methods of the different learning groups and their respective learning styles. The learning methods were rated using a five scale Lickert type questions (Scale 1 for least preferred to Scale 5 most preferred).

The learning styles of the learners were investigated using a number of short questions. The method used was based on the Index of Learning Styles (ILS) by Felder and Silverman. The ILS questionnaire (40 questions) results create a profile that indicates a learner's preferences. A person's learning style profile provides an indication of probably strengths and possible tendencies. According to Felder and Silverman the model has four dimensions of learning styles. Each of the four scales of the index of learning styles has two opposite preferences.

\section{QUESTIONNAIRE RESULTS}

The targeted number of participants of the survey was of 250 amongst a number of European countries. In total 231 participated to questionnaire as outlined in Table 1.

Table 1. Respondents to Questionnaire

\begin{tabular}{|l|c|c|}
\hline & Responses & Target \\
\hline Sweden & 28 & 50 \\
\hline Romania & 55 & 50 \\
\hline Portugal & 46 & 50 \\
\hline Malta & 44 & 50 \\
\hline Italy & 49 & 50 \\
\hline Total: & 231 & 250 \\
\hline
\end{tabular}

\subsection{Learning Content \& Skills Gap}

As can be seen in Table 2, there is an evident divide in the Industry 4.0 technology knowledge of learners with respect to some of the topics. Additive manufacturing, Industrial Internet of Things (IIoT) and Simulation knowledge is in general perceived to be well understood. With respect to cloud computing, collaborative robotics and big data analytics, there is a wider variance in the perceived knowledge, with nearly half of participants indicating that they have poor knowledge in these fields. With respect to data integration and cybersecurity, none of the participants indicated having a very good knowledge in these fields, and the majority of participants indicated as having poor knowledge in these areas. These finding are in line with those found by other researchers in the field [5], [15].

Table 2. Industry 4.0 Technology Knowledge

\begin{tabular}{l|c|c|}
\hline & Average (1-5) & 1 . - 5 \\
\hline Additive Manufacturing & 3.43 & \\
\hline IloT & 3.27 & \\
\hline Augmented \& Virtual Reality & 3.27 & \\
\hline Simulation & 3.19 & \\
\hline Cloud Computing & 2.95 & \\
\hline Autonomous \& Collaborative Robotics & 2.93 \\
\hline Big Data Analytics & 2.58 \\
\hline Horizontal and Vertical Data Integration & 2.40 & \\
\hline Cybersecurity & 2.35 & \\
\hline
\end{tabular}

\subsection{Preferred Learning Methods}

One of the more unexpected results of the questionnaire was the perception of the participants towards virtual/online learning methods. As can be seen in Table 3 there is a clear preference towards face-to-face methods of learning as compared to online methods. Furthermore, participants also preferred the laboratory and case-study based approaches, which demonstrates a more participative approach to learning. As discussed in the next section this correlates to the preferred learning style of the participants.

Further, an analysis on correlation between the Target Groups (TG), i.e. between the "TG1", "TG2" and "TG3" was evaluated. The correlation analysis is presented on Figure 1 a-c. 
Table 3. Preferred Learning Methods

\begin{tabular}{|c|c|c|c|c|c|}
\hline & $\begin{array}{c}\text { TG1 } \\
\text { (Trainers) }\end{array}$ & $\begin{array}{c}\text { TG2 } \\
\text { (Past Learners) }\end{array}$ & $\begin{array}{c}\text { TG3 } \\
\text { (current } \\
\text { Learners) }\end{array}$ & $\begin{array}{l}\text { Target Groups } \\
\text { Combined }\end{array}$ & Distribution \\
\hline Laboratory Work & 4.50 & 4.52 & 4.26 & 4.34 & - \\
\hline Face-to-Face Lecturer & 4.48 & 4.44 & 4.22 & 4.30 & $-\square$ \\
\hline Case Studies & 4.29 & 4.40 & 4.10 & 4.18 & $-a$ \\
\hline Face-to-Face Group Work & 4.42 & 4.24 & 4.05 & 4.16 & $-\nabla$ \\
\hline E-Learning & 3.65 & 3.72 & 3.44 & 3.52 & $-\square$ \\
\hline Online Collaborative Work & 3.87 & 3.44 & 3.24 & 3.11 & -DT \\
\hline
\end{tabular}

Based on the correlation analysis, it could be concluded that there is a good correlation between the target groups, although the correlations between the learners groups is better than between the trainers and the learners groups. This indicates that there is a slight difference between the trainers and the learners groups in preferred learning method, that rise a question to whom to give the preference.

However, the decision on selection of the Preferred Learning Methods is made based on the most prefered methods.

\subsection{Learning Styles}

As illustrated in Figure 2, the participants learning styles show a stronger preference towards an active, sensing and visual learning, and a moderate sequential approach. This correlates with other studies of learning styles which involved engineering participants [19], as well with the participants review of the learning methods as presented in Section 4.2. Active learners tend to retain and understand information best by doing something active with it e.g. discussing or applying it, for example in a laboratory or demonstration session. Whilst not exhibiting a strong preference, respondents preferred a sequential presentation of knowledge which allows them to gain understanding in linear steps, with each step following logically from the previous one.

Further, an analysis on correlation between the Target Groups (TG), i.e. between the "TG1", "TG2" and "TG3" was evaluated. The correlation analysis is presented on Figure 3 a-c.

Based on the correlation analysis, concerning the Learning Styles, it could be concluded that there is a good correlation between the target groups as well.

A higher gap is identified between the trainers and current learners than between the trainers and the past learners. This is an interesting question and an expla- nation could be that the reason for this situation could be a difference in experience between the two learners groups.

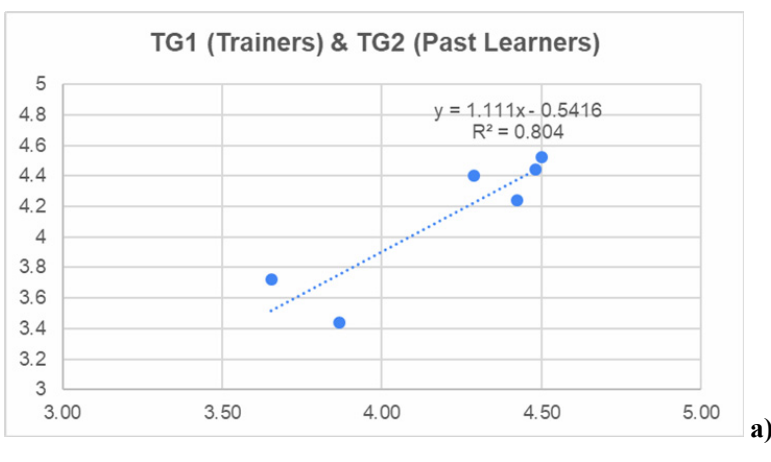

TG1 (Trainers) \& TG3 (Current Learners)

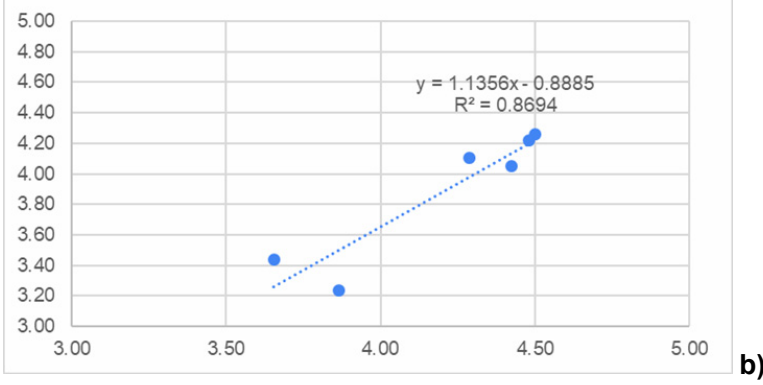

TG2 (Past Learners) \& TG3 (Current Learners)

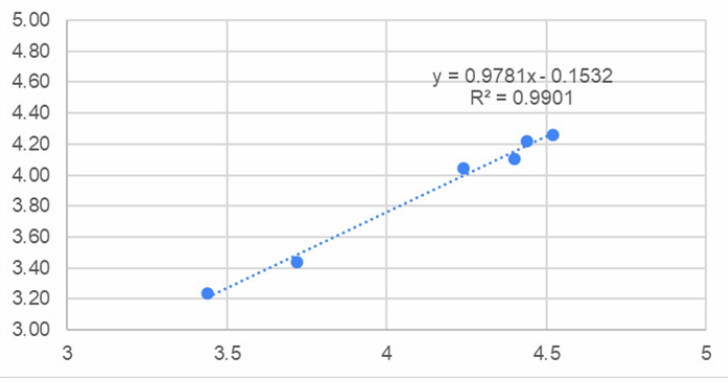

Figure 1. The correlations between the Target Groups on Preferred Learning Methods: a) between trainers and past learners, b) between trainers and current learners, c) between past learners and current learners

However, the decision on selection of the Preferred Learning Styles is made based on the most prefered learning styles, as in the case of the Preferred Learning Methods.

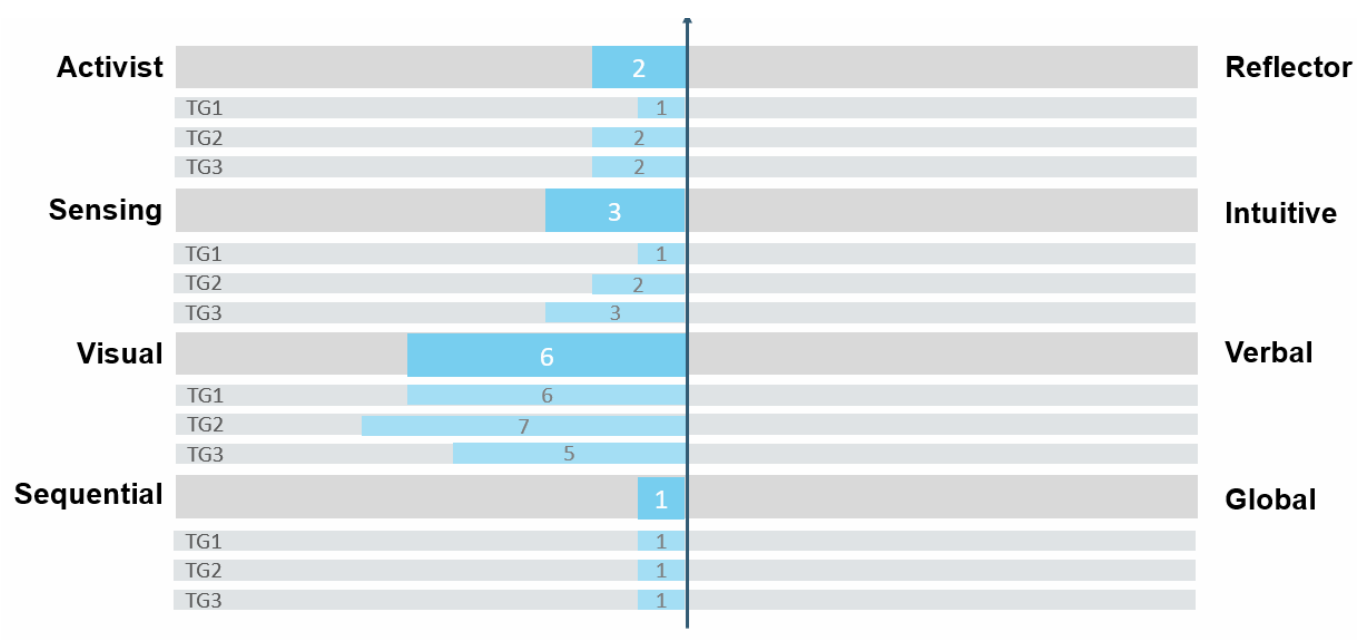

Figure 2. Learning styles of the ICARUS survey participants 


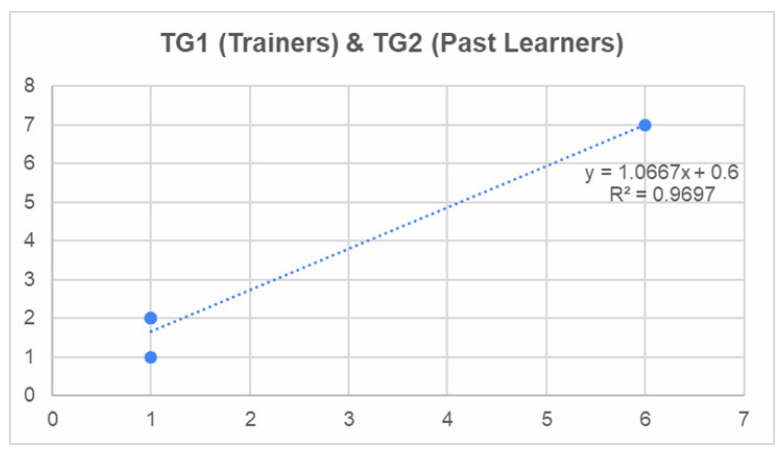

a)

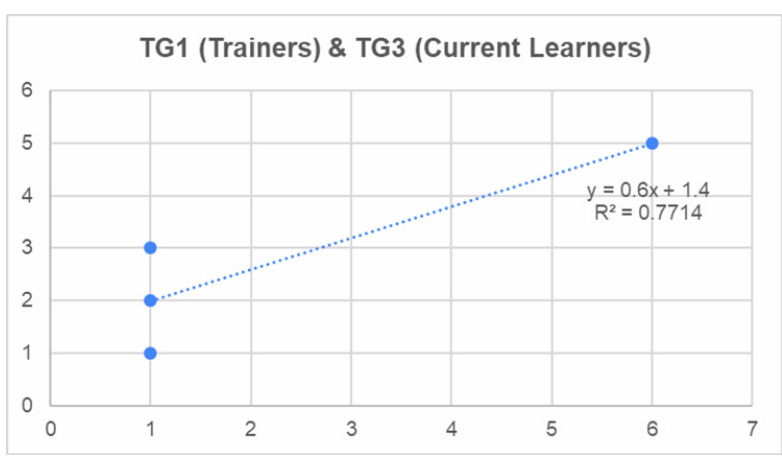

b)

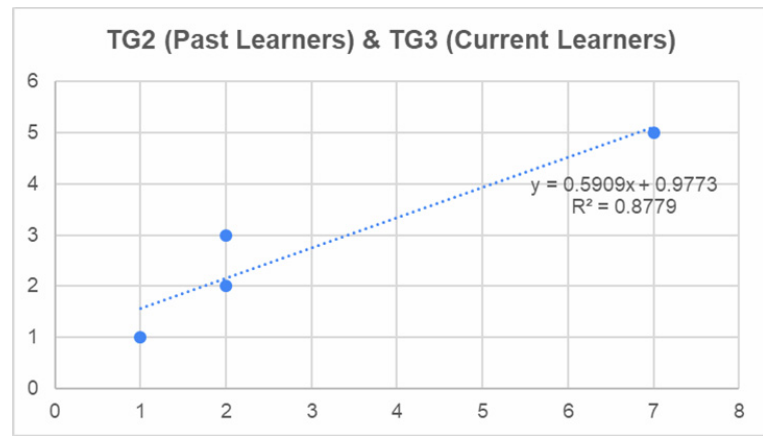

c)

Figure 3. The correlations between the Target Groups on Learning Styles: a) between trainers and past learners, b) between trainers and current learners, c) between past learners and current learners

\section{SPECIFICATIONS OF A DIGITAL TRAINING TOOLBOX FOR INDUSTRY 4.0}

As previously explained the learner and trainer requirements were carefully analysed by a team of experts from different European Universities to develop the specifications for the digital training toolbox.

\subsection{Translating Requirements into Specifications}

An analysis of the learning styles show that the digital training toolbox have a mild preference for sequential presentation of material. The toolbox content therefore needs to be organised into a well organised structure in order to guide the learner. At the same time since only a mild preference is observed, the user should be allowed the flexibility to adapt and access the training content based on their needs.
Since the users also showed a preference towards a sensing learning style the training content must be related and referenced using real-world scenarios and case studies. This content should show how Industry 4.0 technologies and concepts have been adopted and implemented within industry. The active requirement shuold also be fullfiled by developing content which allows the learners to interact in real-time with a physical setup during the learning experience. If active/participative activities cannot be carried out in class/during learning, an group activity or applied assignment is recommended.

Both the sensing and active requirements are also corraborated by the preferered learning methods illustrated by the user which suggest that laboratory work, face-to-face and case-studies are favored. Finally a moderate to strong preference was shown for visual learning content. Hence the training content must use diagrams, sketches, schematics, photographs, flow charts, or any other visual representation of course material as neccesary. The transaltion of the requirements into the digital training toolbox requirements is summarised in Table 4.

Table 4. Translating requirements into specifications

\begin{tabular}{|l|l|l|}
\hline $\begin{array}{l}\text { Requirements } \\
\text { "What" }\end{array}$ & $\begin{array}{l}\text { Specifications } \\
\text { "How" }\end{array}$ \\
\hline Sequential & => & $\begin{array}{l}\text { The content needs to be organised into a well } \\
\text { structured format providing a logical flow and } \\
\text { sequence. The material must be presented in a } \\
\text { sequential manner, with a clear path to follow, which } \\
\text { can also allow a degree of flexibility if required by the } \\
\text { learner. }\end{array}$ \\
\hline Sensing & $=\begin{array}{l}\text { To remember and understand information best } \\
\text { training content must be connected/referenced to } \\
\text { real world scenarios, e.g. through case studies. }\end{array}$ \\
\hline Active & $\Rightarrow \begin{array}{l}\text { Content must allow active learners to interact in real- } \\
\text { time with a physical setup during the learning } \\
\text { experience. }\end{array}$ \\
\hline Visual & $=\begin{array}{l}\text { The digital training toolbox content must use } \\
\text { diagrams, sketches, schematics, photographs, flow } \\
\text { charts, or any other visual representation as } \\
\text { necessary. }\end{array}$
\end{tabular}

\subsection{Digital Training Toolbox for Industry 4.0}

The requirements analysis has led to the conclusion that to appropiately address the Industry 4.0 skills gap and mismatches an open and digital training toolbox needs to be developed. This digital training toolbox can be utilised by HEI trainers to educate both current and previous generations of HEI learners in Industry 4.0 technologies. As per the specifications outlined in Table 4., the toolbox needs to contain a modular set of content which targets the skills gap in Industry 4.0 identified. This content needs to be provided in a structured, visual and interesting manner. It must also be supported by a set of case studies which illustrate how Industry 4.0 technologies and concepts have been applied in industry. Furthermore, a mobile training unit must be developed which allows users to interact in real-time with a physical setup during the learning experience. The contents of the digital training toolbox for Industry 4.0 are therefore illustrated in Figure 4. 
ICARUS Digital Training Toolbox

For Industry 4.0

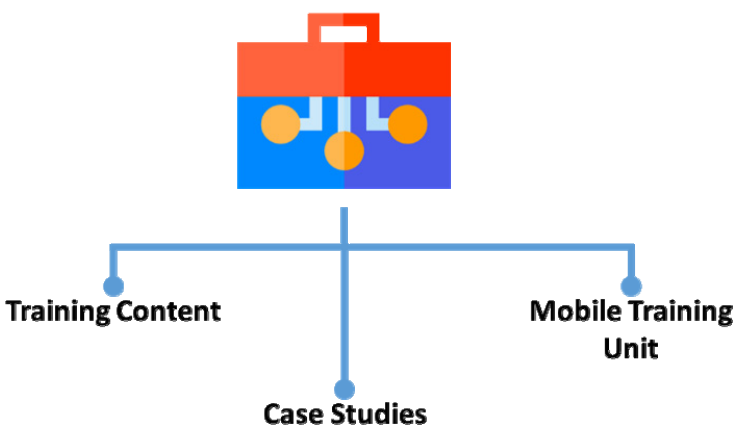

Figure 4. ICARUS Digital Training Toolbox for Industry 4.0

\section{CONCLUSIONS \& FUTURE WORK}

The quantitative research methodology employed by this study has resulted in a better understanding of the knowledge gaps in Industry 4.0 technologies which need to be tackled in order to achieve implementation. That said it is considered critical that any training content to be developed would not only tackle the technological knowledge, but would also be complemented with knowledge about how to drive digital transformation and change within an organization and address aspects such as ethical considerations and innovative training concepts. To develop an effective pedagogic approach to address this Industry 4.0 skills gap the ICARUS open and digital training toolbox, which are the main aim of this project, the specific training requirements of HEI educators and learners have also been defined. This information will therefore be utilized in order to develop effective training content which is specifically targeted towards the preferred learning method and styles of the learner.

This paper has therefore presented how the ICARUS project partners have developed and undertaken a study to understand the training requirements of HEI educators and learners and how these were translated these into the specifications for a Digital Training Toolbox.

The analysis of this information has provided the underlying foundation for the continuation of this research. In future work this will lead to the development of the ICARUS Digital Industry 4.0 Training Toolbox which addresses the needs of HEI trainers and learners. The next and step of this work will therefore be to develop the eLearning content, case studies and mobile training unit and evaluate these with the trainers and learners in a participative learning environment.

\section{ACKNOWLEDGMENTS}

The authors would like to thank the EUPA Malta for funding of ICARUS - An Innovative Higher Education Institution Training Toolbox to EffeCtively AddRess the EUropean InduStry 4.0 Skills Gap and Mismatches via Erasmus+ Project No. 2019-1-MT01-KA203051265 (icarusproject.edu.mt).

This work has been supported by FCT - Fundação para a Ciência e Tecnologia within the R\&D Units Project Scope: UIDB/00319/2020.

\section{REFERENCES}

[1] Putnik, G.D., Ferreira, L., Lopes, N., Putnik, Z. What is a Cyber-Physical System: Definitions and models spectrum, FME Transactions, Vol. 47, No. 4, pp. 663-674, 2019

[2] Pinheiro, P., Putnik, G., Castro, A., Castro, H., Fontana, R., Romero, F. Industry 4.0 and industrial revolutions: An assessment based on complexity. FME Transactions, Vol. 47, No. 4, pp. 831-840, 2019.

[3] Stadnicka, D., Litwin, P., Antonelli, D. Human factor in industry of the future: Knowledge acquisition and motivation. FME Transactions, Vol. 47, No. 4, pp. 823-830, 2019.

[4] Joksimović, A. D., Veg, E. A., Simonović, V. D., Regodić, M. M., Šiniković, G. B., \& Gubeljak, N. Implementation of inverted classroom methodology in 3D modeling course. FME Transactions, Vol. 47, No. 2, pp. 310-315, 2019.

[5] Motyl, B., Baronio, G., Uberti, S., Speranza, D., Filippi, S. How will Change the Future Engineers Skills in the Industry 4.0 Framework? A Questionnaire Survey, Procedia Manuf., Vol. 11, pp. 1501-1509, 2017.

[6] Asian Development Bank. Moving toward knowledge-based economies: Asian experiences. Regional Sustainable Development Department, Asian Development Bank. 2007.

[7] Chu, S.K.W., et al. Introduction. In 21st century skills development through inquiry-based learning from theory to practice. Springer International Publishing, 2021

[8] Quinton, S.R., Allen, M.M. The social processes of web 2.0 collaboration: Towards a new model for virtual learning. In: Curriculum models for the 21st century. Springer, New York, NY, 2014. p. 35-53.

[9] Coşkun, S.; Kayikci, Y.; Gençay, E. Adapting engineering education to industry 4.0 vision. Technologies, 2019, Vol. 7, No. 110.

[10] Huang, Ronghuai; Spector, J. Michael; Yang, Junfeng. Introduction to Educational Technology. In: Educational technology: a primer for the 21st century. Springer, 2019.

[11] Maxwell, G. S. Defining standards for the 21st century. In: Educational assessment in the 21st Century. Springer, Dordrecht, 2009. p. 263-286.

[12] Gerstein, Jackie. Moving from education 1.0 through education 2.0 towards education 3.0. 2014.

[13] Putnik, Goran; Carvalho, Carlos; Alves, Cátia. Education 3.0 and Social Network-based Education: An Implementation Framework and Experiment at the University of Minho for Education and Training in Quality Management, in Proceedings of 9th International Quality Conference. 2015. Kragujevac, Serbia, pp. 675-680.

[14]Mason, Mark. Complexity theory and the philosophy of education. Educational philosophy and theory, 2008, 40.1: 4-18. 
[15] Nafea, R.M.E.D., Toplu, E.K., Future of Education in Industry 4.0: Educational Digitization - A Canadian Case Study, Business Management and Communication Perspectives in Industry 4.0, 2020.

[16] Schuster, K., Plumanns, L., Groß, K., Vossen, R., Richert, A., Jeschke, S. Preparing for Industry $4.0-$ Testing Collaborative Virtual Learning Environments with Students and Professional Trainers, Int. J. Adv. Corp. Learn. IJAC, Vol. 8, No. 4, pp.14-20, 2015.

[17]Felder, R.M., Silverman, L.K. Learning and Teaching Styles in Engineering Education, Eng. Educ., Vol. 78, No. 7, pp. 674-81, 1988.

[18] Othman. N., Amiruddin, M.H. Different Perspectives of Learning Styles from VARK Model, Procedia - Soc. Behav. Sci., Vol. 7, pp. 652-660, 2010.

[19] Ayre, M., Hands, D., Mills, J., Kentish, P., Learning about Learning Styles: Can This Improve Engineering Education?', Mountain Rise, Vol. 2, No.1, pp. 1-16, 2005

[20] Huang, E.Y., Lin, S.W., Huang, T.K., What type of learning style leads to online participation in the mixed-mode e-learning environment? A study of software usage instruction, Comput. Educ., Vol. 58, No. 1, pp. 338-349, 2012.

[21] Borrego, M., Douglas, E.P., Amelink, C.T., Quantitative, Qualitative, and Mixed Research Methods in Engineering Education, J. Eng. Educ., Vol. 98, No. 1, pp. 53-66, 2009.

\section{СПЕЦИФИКАЦИЈЕ ДИГИТАЛНОГ СКУПА АЛАТА ЗА ТРЕНИНГ ЗА ИНДУСТРИЈУ 4.0}

\section{Е. Франкаланза, Ј. Борг, Е. Раух, Г. Д. Путник, К. Алвеш, М. Лундгрен, К. Амза,}

Развој технологије Индустрије 4.0 у последњој деценији донео је произвођачима многе нове могућности. Повећана дигитализација производних операција довела је до нових начина производње и развоја производа. Ова дигитализација је такође повећала количину сензорских података који су лако доступни и који се могу користити за подршку доношењу одлука у реалном времену. Међутим, уз прилике долазе и бројни изазови. Јеадн од главних међу њима је јаз у вештинама радне снаге. Без потребног знања организацијама ће бити тешко и сложено не само да користе ове технологије, већ и да развију сутрашње нове парадигме производње. Отуда је потребна иновативна и ефикасна методологија обуке како би се превазишао овај јаз вештина и знања.

Као део развоја ове методологије, овај рад представља налаз студије спроведене ради анализе јаза у знању и вештинама, пожељних метода и стилова учења предавача, садашњих и бивших студената на високошколским инжењерским установама. Ова анализа захтева довела је до спецификација Дигиталног скупа алата за обуку, који се може користити за подршку имплементацији технологија и организационих концепата Инудстрије 4.0. 